\title{
Perspectives of Sickle Cell Disease Stakeholders on Heritable Genome Editing
}

\author{
Brittany M. Hollister, ${ }^{1}$ Mariclare C. Gatter, ${ }^{1}$ Khadijah E. Abdallah, ${ }^{1}$ Alyssa J. Armsby, ${ }^{2,3}$ Ashley J. Buscetta, \\ Yen Ji Julia Byeon, ${ }^{1}$ Kayla E. Cooper, ${ }^{1}$ Stacy Desine, ${ }^{1}$ Anitra Persaud, ${ }^{1,4}$ Kelly E. Ormond, ${ }^{2,5}$ and Vence L. Bonham ${ }^{1, *}$
}

\begin{abstract}
Advances in CRISPR technology and the announcement of the first gene-edited babies have sparked a global dialogue about the future of heritable genome editing (HGE). There has been an international call for public input to inform a substantive debate about benefits and risks of HGE. This study investigates the views of the sickle cell disease (SCD) community. We utilized a mixed-methods approach to examine SCD stakeholders' views in the United States. We found SCD stakeholders hold a nuanced view of HGE. Assuming the technology is shown to be safe and effective, they are just as supportive of HGE as genetics professionals, but more supportive than the general public. However, they are also concerned about the potential implications of HGE, despite this support. As discourse surrounding HGE advances, it is crucial to engage disease communities and other key stakeholders whose lives could be altered by these interventions.
\end{abstract}

\section{Introduction}

The global scientific community is currently engaged in discourse regarding how to guide responsible heritable genome editing (HGE) research ethically, including discussion around if it should even continue. ${ }^{1}$ Debate concerning this technology has intensified since the announcement of the birth of the first gene-edited babies in November of $2018 .^{2-6}$ Following this, many scientists expressed concern with the immediate future of this technology and supported a ban or moratorium on HGE research. ${ }^{7-9}$ International groups of researchers called for expanded discussion of the medical, social, ethical, and moral implications of HGE before any clinical use be permitted. ${ }^{9}$

Currently, the long-term biological consequences of HGE are not understood, and the consensus of the scientific community is that HGE is not safe or effective for use in the clinic. ${ }^{9}$ In the United States, there is a ban on clinical trials in which a human embryo is intentionally created for or modified by HGE. ${ }^{10}$ The scientific community has called for the development of a broad societal consensus on the appropriateness of HGE research. ${ }^{9}$ While many published scientific commentaries on the issue exist, there are limited empirical studies of the opinions and attitudes of individuals living with genetic dis- eases, and reaching a consensus requires the inclusion of these opinions. ${ }^{4,11-13} \mathrm{We}$ aim to integrate their views into the scientific and public discourse on HGE. This study reports attitudes and opinions of individuals from one disease community: sickle cell disease (SCD). SCD is particularly relevant to the gene-editing debate, given that somatic genome editing (SGE) clinical trials are underway. ${ }^{14,15}$

Opinion surveys of scientists on genome editing as reported in Armsby et al. are essential in developing a consensus on clinical uses of HGE, due to their expertise in the field. ${ }^{16}$ The scientific community, however, must also engage the general public and disease communities, as these advances carry major societal implications. However, when surveying the public, it can be challenging to communicate complex topics such as gene editing without compromising the technical accuracy that ensures informative, reliable data. ${ }^{17,18}$ As a result, highly variable language in current opinion surveys has led to inconsistency between study results. ${ }^{19}$ When examining the variety of studies on the topic, it is evident that even small changes in language can significantly affect how survey participants respond. ${ }^{19}$ In our study, we sought to address this issue so that the reported views of SCD stakeholders are informed and reflected accurately.

${ }^{1}$ Social and Behavioral Research Branch, National Human Genome Research Institute, National Institutes of Health, Bethesda, Maryland; ${ }^{2}$ Department of Genetics and ${ }^{5}$ Stanford Center for Biomedical Ethics, Stanford School of Medicine, Stanford University, Stanford, California; ${ }^{3}$ Department of Cardiology, John Radcliffe Hospital, Oxford University Hospitals NHS Foundation Trust, Oxford, United Kingdom; and ${ }^{4}$ Perelman School of Medicine, University of Pennsylvania, Philadelphia, Pennsylvania. 


\section{Methods}

Study population and recruitment

We conducted a mixed-methods study, which included an initial survey, an educational video on CRISPR genome editing developed by the research team, a post-video survey, and 15 moderated focus groups: six groups of individuals with SCD, six parent groups, and three groups of physicians who care for individuals living with SCD. ${ }^{20}$ For this study, we analyzed the 12 focus groups of the individuals with SCD and parents only. Inclusion was limited to English-speaking adults who were at least 18 years of age. Participants were recruited from the Mid-Atlantic and Southern regions of the United States between April and December 2017. Demographic information was collected, and each participant received compensation for their participation. This study was reviewed and approved by the Institutional Review Board at the National Human Genome Research Institute (NHGRI; NCT03167450).

\section{Administration of focus groups and study instruments}

Trained moderators (A.P. and V.B.) led focus groups using a discussion guide. The discussion guide was developed by A.P. and V.B. with input from researchers conducting basic gene-editing and SCD research, as well as participants from the three pilot focus groups. V.B. is an experienced qualitative researcher, and A.P. is a pre-doctoral fellow trained in qualitative methods. The discussion guide was intended to (1) assess development of the educational video tool broadly for the public on CRISPR/Cas9 and (2) study qualitatively the attitudes, beliefs, and opinions of individuals with SCD, parents of individuals with SCD, and providers regarding geneediting research, and the clinical use of gene editing for SCD. The discussion guide was divided into three parts: (1) educational video, (2) gene-editing attitudes and beliefs, and (3) input for the research community. Participants were asked open-ended questions about each theme with follow-up probes.

Individuals with SCD and parents participated in focus group sessions separately. Before the focus groups began, all participants completed the Genetic Literacy and Comprehension (GLAC) instrument to measure familiarity with genetic terms ${ }^{21}$ and a researcher-developed CRISPR knowledge questionnaire as part of the prevideo survey. After the initial survey, participants watched the researcher-created 15-minute educational video, which covered gene editing, the function of CRISPR, CRISPR's potential role in treating SCD, a comparison of SGE and HGE, and the ethical issues surrounding the use of CRISPR and human embryo editing. The participants then com- pleted the post-video CRISPR knowledge questionnaire. Focus groups were audio recorded with the participants' permission, transcribed verbatim, and anonymized.

Following the focus group, the participants answered a quantitative survey consisting of 53 questions. Of those questions, 14 focused on germline-editing concepts. We chose to refer to germline gene editing as HGE in this article. While we used the terms "somatic" and "germline" to differentiate between editing methods in our study, we believe "heritable gene editing" underscores the unique aspect of this editing without using scientific or technical language.

Eight of those 14 questions were derived from the national Pew Research Center survey of U.S. adults conducted March 2-28, 2016. ${ }^{22}$ Specific questions can be seen in Supplementary Data 1 . The remaining six questions were obtained from a 2017 study conducted by Armsby et al. that examined the viewpoints of genetics professionals toward gene editing. ${ }^{16}$ To assess differences in opinions of stakeholders regarding HGE and SGE, we examined four questions regarding the acceptability of each technology. These questions provided a brief definition of somatic and germline gene editing, and then assessed participants' beliefs about each (Supplementary Data 2).

\section{Analyses}

Transcripts were analyzed for themes, as previously described. $^{20}$ Two independent reviewers (A.P. and S.D.) obtained a final kappa coefficient of 0.82 and percentage agreement scores of at least $90 \%$ across all transcripts. HGE-specific qualitative themes were determined by additional coding (K.C. and S.D.). The interpretation of these codes included comparing theme frequencies, identifying theme co-occurrence, and classifying relationships between different themes. Descriptive statistics were calculated for demographic variables.

Chi-square tests were performed to assess differences between responses from our study population to the Pew and Armsby et al. surveys. The qualitative analysis was performed in NVivo v12 (QSR International, Melbourne, Australia), while the quantitative analyses were performed using R software (R Foundation for Statistical Computing, Vienna, Austria), and a $p$-value of $\leq 0.05$ was used to determine statistical significance.

\section{Results}

Population description

The demographics of those enrolled in the study were previously described by Persaud et al. ${ }^{20}$ Eighty-seven study participants identified as either individuals with SCD or parents of individuals with SCD. The majority 
were female and self-identified as African American (Table 1). As a result, we compared our population to African Americans in the Pew study in addition to the general population. Individuals with SCD were slightly more educated than the parents, with $52 \%$ of individuals with SCD reporting a bachelor's degree or higher compared to $43 \%$ of parents. Finally, in terms of religiosity, most individuals with SCD (69\%) and parents (82\%) reported carrying religion into their life and being very/moderately spiritual (90\% individuals with SCD vs .95\% parents; Table 1).

Prior to participating in the study, $49.4 \%$ of SCD stakeholders indicated they had not heard of HGE at all. Only $10.4 \%$ indicated that they had heard a lot about the idea, while $35.6 \%$ indicated they had heard a little about the idea. This was slightly different from the general population in the Pew survey, where $11.1 \%$ indicated they had heard a lot about HGE, $53.1 \%$ said they had heard a little about the idea, and $34.8 \%$ stated they had not heard about HGE at all $\left(\chi^{2}=10.47\right.$, $p=0.005)$. There was no difference between the response

Table 1. Demographic characteristics of sickle cell disease stakeholders

\begin{tabular}{|c|c|}
\hline Characteristic & $\begin{array}{c}\text { Individuals with } S C D \\
\text { and parents, } \mathrm{N}=87\end{array}$ \\
\hline \multicolumn{2}{|l|}{$\operatorname{Sex}(n, \%)$} \\
\hline Female & $65,75 \%$ \\
\hline Male & $20,23 \%$ \\
\hline Missing & $2,2 \%$ \\
\hline Age, years $(M \pm S D)$ & $43.5 \pm 14.4$ \\
\hline \multicolumn{2}{|l|}{ Birthplace $(n, \%)$} \\
\hline United States & $69,83 \%$ \\
\hline Sub-Saharan Africa & $5,6 \%$ \\
\hline Caribbean & $6,7 \%$ \\
\hline Other & $3,4 \%$ \\
\hline \multicolumn{2}{|l|}{ Self-identified ethnicity $(n, \%)$} \\
\hline African American & $74,86 \%$ \\
\hline Hispanic/Latino & $2,2 \%$ \\
\hline Other & $8,9 \%$ \\
\hline Missing & $3,3 \%$ \\
\hline \multicolumn{2}{|l|}{ Educational level $(n, \%)$} \\
\hline High school or less & $6,7 \%$ \\
\hline Some college & $37,43 \%$ \\
\hline Bachelor's degree & $13,15 \%$ \\
\hline Master's degree or higher & $28,32 \%$ \\
\hline Missing & $3,3 \%$ \\
\hline \multicolumn{2}{|c|}{$\begin{array}{l}\text { How much do you try to carry your religion over into all other dealings } \\
\text { in your life? }(n, \%)\end{array}$} \\
\hline A great deal/quite a bit & $58,67 \%$ \\
\hline Some/a little & $12,14 \%$ \\
\hline Not at all & $9,10 \%$ \\
\hline Missing & $8,9 \%$ \\
\hline \multicolumn{2}{|c|}{ How spiritual would you say you are? $(n, \%)$} \\
\hline Very spiritual & $45,52 \%$ \\
\hline Moderately/slightly spiritual & $31,36 \%$ \\
\hline Not spiritual at all & $3,3 \%$ \\
\hline Missing & $8,9 \%$ \\
\hline \multicolumn{2}{|c|}{ Are you involved in a SCD support or advocacy group $(\mathrm{s}) ?(n, \%)$} \\
\hline Yes & $59,68 \%$ \\
\hline No & $23,32 \%$ \\
\hline
\end{tabular}

$S D$, standard deviation; $\mathrm{SCD}$, sickle cell disease. of the SCD stakeholders and the African Americans who participated in Pew survey regarding prior knowledge of HGE $\left(\chi^{2}=2.23, p=0.33\right)$.

\section{Distinction between SGE and HGE}

We observed differences in support for SGE versus HGE among SCD stakeholders. While most SCD stakeholders were either neutral or agreed that both SGE and HGE are morally acceptable (Fig. 1), more SCD stakeholders felt that SGE is morally acceptable than $\operatorname{HGE}\left(\chi^{2}=7.39\right.$, $p=0.02$ ). Additionally, more stakeholders did not believe HGE is morally acceptable when compared to the same question about SGE (Fig. 1). Furthermore, more SCD stakeholders disagreed that HGE is acceptable, even when no other treatments were available when compared to those who disagreed that SGE is acceptable in the same condition.

\section{Support for HGE}

Assuming it is safe and effective, most SCD stakeholders indicated support of clinical HGE research in addition to HGE leading to the possibility of having a healthy baby in the future. Both SCD stakeholders and genetics professionals were supportive of parents' right to edit the genes of their children prior to birth to provide the possibility of a healthy baby, as well as the use of HGE if alternative treatments are more expensive or not available (Table 2).

Compared to the general population in the United States, however, SCD stakeholders were significantly more supportive of the future use of HGE (Fig. 2). This was especially true when compared to African Americans, who were even less supportive of HGE than the general population (Fig. 2 and Table 3). Assuming it is safe and effective, SCD stakeholders more frequently indicated that they would want HGE for their child, were more positive about the possibility of HGE for society, and were more supportive of using the technology to improve the health of children than the general population and African Americans (Fig. 2 and Table 3). This support is reflected in the themes from the stakeholder focus group discussions (Table 4). Participants were encouraged that HGE could eradicate the disease.

I suffered a lot as a child, more as a child than as an adult. And I would never in my whole life want anybody to suffer like I did ... If I can like not have anyone-and I don't have kids but in the future, if ... no child would ever have to be born with this thing, that would be my choice. (Individual with $\mathrm{SCD}$ )

Furthermore, stakeholder groups discussed the hope of not worrying about passing down SCD to their future offspring through the utilization of HGE. 

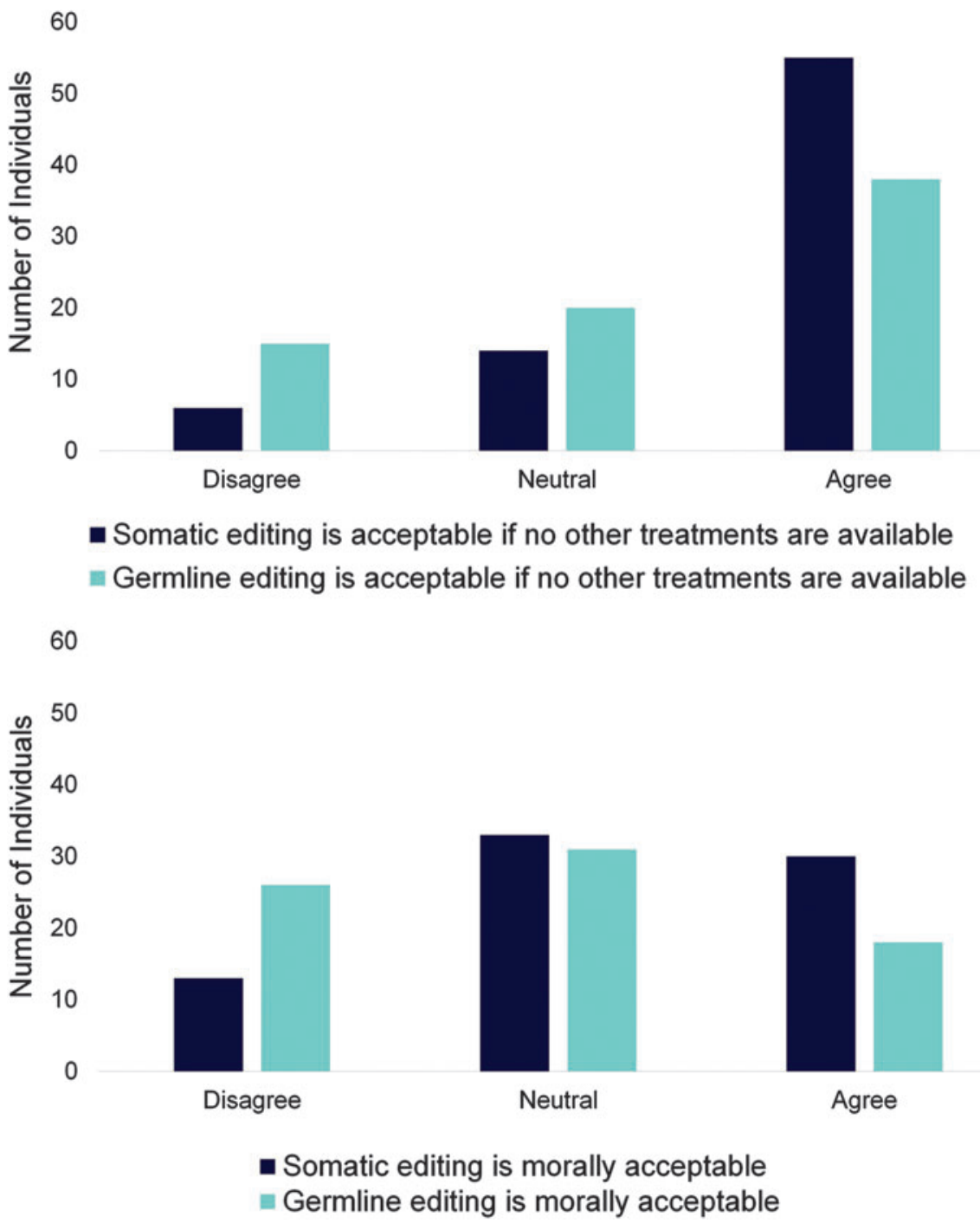

FIG. 1. Sickle cell disease (SCD) stakeholders find somatic genome editing (SGE) more acceptable than heritable (germline) genome editing (HGE). While most SCD stakeholders find both SGE and HGE acceptable if no other treatments are available, more individuals find SGE acceptable under these conditions $\left(\chi^{2}=7.99, p=0.02\right)$. When asked about moral acceptability, SCD stakeholders feel that SGE is acceptable when compared to HGE $\left(\chi^{2}=7.39, p=0.02\right)$.

I think the problem with bone marrow transplant now is you can cure the patient, but they can pass on the disease. At some point, why would you limit the target of the cure to just one life when you could affect future generations? (Parent)

\section{Concerns about HGE}

Despite this support, SCD stakeholders were equally as worried about the possibility of HGE as the general U.S. population (Fig. 2). Both the general population and SCD stakeholders felt HGE could lead to more downsides than benefits or equal downsides and benefits for society (Table 3). These concerns were expressed within the con- text of personal morality. This was clear, as SCD stakeholders more frequently stated that HGE goes against their cultural or religious beliefs than genetics professionals (Table 2). Furthermore, fewer SCD stakeholders felt that HGE was morally acceptable when compared to genetics professionals (Table 2). These concerns were also reflected in stakeholder focus group discussions. Specifically, some stakeholders felt that permanently altering DNA constitutes a violation of their religious beliefs.

If I touch anything that He said is perfect, then I'm out of His will, so when it comes to ethics, it's me following Him or me doing my own thing, and I think doing my own thing would be to alter something that He said is perfect. (Parent) 
Table 2. Comparison of SCD stakeholders with genetics professionals

\begin{tabular}{|c|c|c|c|}
\hline & $\begin{array}{c}\text { Patients/ } \\
\text { parents, } \\
\mathrm{N}=75\end{array}$ & $\begin{array}{c}\text { Genetics } \\
\text { professionals, } \\
\mathrm{N}=472\end{array}$ & $\underset{\text { p-value }}{\chi^{2}}$ \\
\hline \multicolumn{4}{|c|}{$\begin{array}{l}\text { Parents and guardians have a right to edit genes of their children before } \\
\text { they are born }\end{array}$} \\
\hline Agree strongly/agree & $33(44.0 \%)$ & $207(43.9 \%)$ & $0.036, p=0.98$ \\
\hline Neutral & $19(25.3 \%)$ & $124(26.3 \%)$ & \\
\hline Disagree strongly/disagree & $23(30.7 \%)$ & $141(29.9 \%)$ & \\
\hline Missing & $0(0 \%)$ & $0(0 \%)$ & \\
\hline \multicolumn{4}{|c|}{$\begin{array}{l}\text { Germline human gene editing is acceptable if alternative treatments are } \\
\text { more expensive }\end{array}$} \\
\hline Agree strongly/agree & $29(38.7 \%)$ & $180(38.1 \%)$ & $2.48, p=0.48$ \\
\hline Neutral & $23(30.7 \%)$ & $115(24.4 \%)$ & \\
\hline Disagree strongly/disagree & $22(29.3 \%)$ & $174(36.9 \%)$ & \\
\hline Missing & $1(1.3 \%)$ & $3(0.6 \%)$ & \\
\hline \multicolumn{4}{|c|}{$\begin{array}{l}\text { Germline human gene editing is acceptable if there are no alternative } \\
\text { treatments available }\end{array}$} \\
\hline Agree strongly/agree & $38(50.7 \%)$ & $286(60.6 \%)$ & $3.20, p=0.36$ \\
\hline Neutral & $20(26.7 \%)$ & $99(21.0 \%)$ & \\
\hline Disagree strongly/disagree & $15(20.0 \%)$ & $81(17.2 \%)$ & \\
\hline Missing & $2(2.7 \%)$ & $6(1.3 \%)$ & \\
\hline \multicolumn{4}{|c|}{ Germline human gene editing goes against my cultural beliefs } \\
\hline Agree strongly/agree & $19(25.3 \%)$ & $65(13.8 \%)$ & $12.44, p=0.006$ \\
\hline Neutral & $20(26.7 \%)$ & $82(17.4 \%)$ & \\
\hline Disagree strongly/disagree & $36(48.0 \%)$ & $320(67.8 \%)$ & \\
\hline Missing & $0(0 \%)$ & $5(1.1 \%)$ & \\
\hline \multicolumn{4}{|c|}{ Germline human gene editing goes against my religious beliefs } \\
\hline Agree strongly/agree & $16(21.3 \%)$ & $52(11.0 \%)$ & $12.83, p=0.005$ \\
\hline Neutral & $18(24.0 \%)$ & $69(14.6 \%)$ & \\
\hline Disagree strongly/disagree & $40(53.3 \%)$ & $345(73.1 \%)$ & \\
\hline Missing & $1(1.3 \%)$ & $4(0.9 \%)$ & \\
\hline \multicolumn{4}{|c|}{ Germline human gene editing is morally acceptable } \\
\hline Agree strongly/agree & $18(24.0 \%)$ & $225(47.7 \%)$ & $16.29, p=0.001$ \\
\hline Neutral & $31(41.3 \%)$ & $147(31.1 \%)$ & \\
\hline Disagree strongly/disagree & $26(34.7 \%)$ & $95(20.1 \%)$ & \\
\hline Missing & $0(0 \%)$ & $5(1.1 \%)$ & \\
\hline
\end{tabular}

Bold values indicate statistical significance.

Other concerns included apprehension over the unknown side effects of $\mathrm{HGE}$ and its impact on future generations.

I don't think I would be comfortable with it. If I'm not sure how it's going to affect my child, I don't want it to affect my grandchildren. (Parent)

Stakeholders also expressed broader societal concerns about HGE. One prevalent concern was the potential use of HGE to alter non-disease traits, such as physical appearance (Table 4). Stakeholders were not supportive of the use of HGE technology to alter these traits and voiced fears about the creation of "designer babies."

On the other hand, like the designer babies and that sort of thing, it seems like sometimes you are playing with things that maybe should not be played with because it can go in a whole other direction that can be potentially more detrimental than beneficial. (Parent)

\section{Discussion}

Our study suggests that SCD stakeholders are more supportive of HGE than the general population in the United States and equally as supportive as genetics professionals. However, despite their increased positivity, SCD stakeholders reported the same degree of concern about HGE's associated risks compared to the general population and more concern compared to genetics professionals.

The perspectives of SCD stakeholders share similarities to those of genetics professionals, ${ }^{3,4,7,23}$ but there were also key differences that should be considered. Compared to genetics professionals, SCD stakeholders were just as accepting of HGE being used as a medical treatment if it is determined to be safe and effective in the future. This could be attributed to the fact that SCD stakeholders and genetics professionals share an increased familiarity with and personal investment in the future of genomeediting technologies, albeit from different perspectives. While genetics professionals were likely to consider these technologies in the broader context of medical advancement and societal progress, our qualitative data show that SCD stakeholders considered these technologies in the context of their own lives and those of their children.

We identified a significant difference of opinion between SCD stakeholders and genetics professionals in three successive questions that asked whether HGE conflicted with personal moral, religious, and cultural values. On each of these questions, SCD stakeholders were significantly more likely than genetics professionals to identify conflicts with their personal value system. It is possible that this variance was related to differences in self-identified religiosity between SCD stakeholders and genetics professionals. However, despite this characteristic, our population was nonetheless more likely than the general population to report wanting HGE for a hypothetical future child if it is safe and effective. Therefore, SCD stakeholders did not demonstrate the same negative correlation between increased religiosity and support for clinical use of HGE reported by Pew in 2016. ${ }^{22}$ This finding suggests that our cohort distinguishes between moral approval of the technology and support of its medical use. Our cohort's increased support for HGE despite high religiosity and moral disapproval when compared to genetics professionals suggests that disease burden may be more influential than either of the aforementioned factors on support for HGE.

In our quantitative data, SCD stakeholders reported being more optimistic about the prospect of HGE but equally as worried as the public. In our focus group sessions, SCD stakeholders identified many of the same associated risks that the public did when asked about HGE. In discussions, SCD stakeholders' most common 


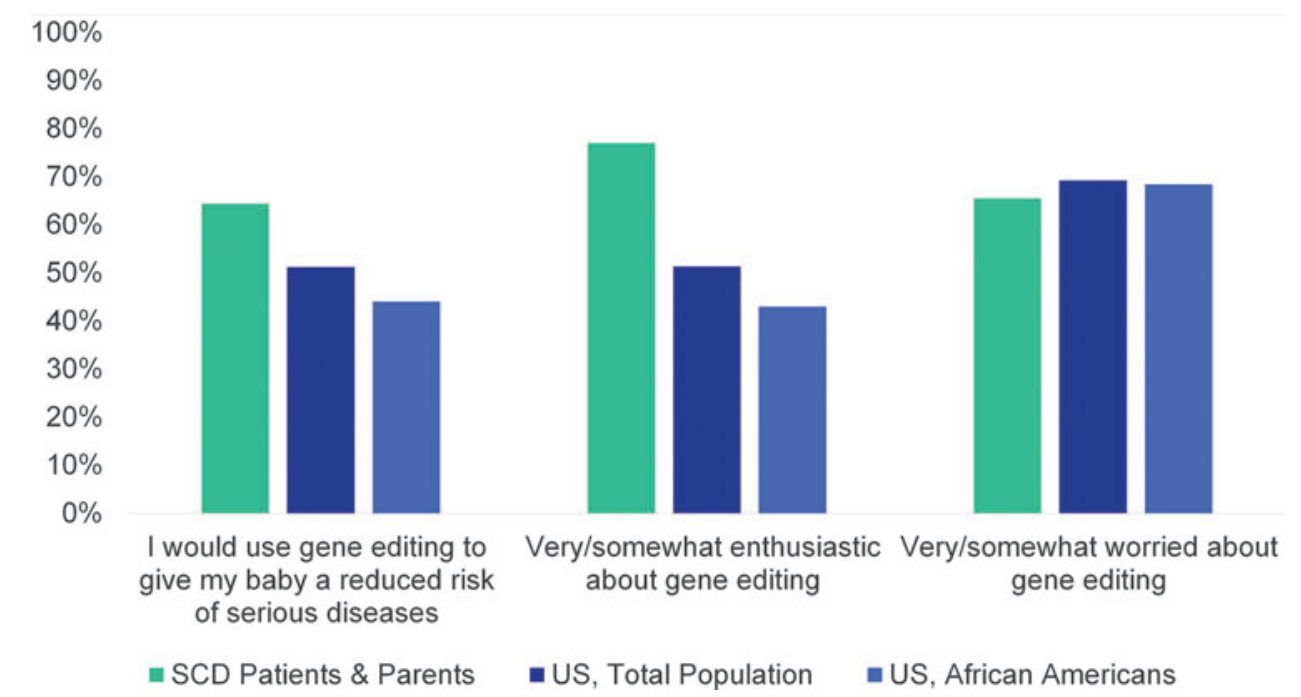

FIG. 2. SCD holders, while equally worried, are more enthusiastic about and more likely to use HGE than the public if it provides a much-reduced risk of serious diseases for their child. Significantly more SCD stakeholders indicated that they probably or definitely would use HGE to give their baby a much-reduced risk of serious diseases or conditions over his/her lifetime when compared to the general population from Pew $\left(\chi^{2}=13.92, p=0.0002\right)$ and African Americans from Pew $\left(\chi^{2}=21.33, p<0.0001\right)$. This pattern was consistent when participants were asked about how enthusiastic they were about the possibility of HGE for society as a whole. SCD stakeholders were more enthusiastic than the general Pew population $\left(\chi^{2}=27.21, p<0.0001\right)$ and Pew African Americans $\left(\chi^{2} \geq 38.67\right.$, $p<0.0001)$. However, SCD stakeholders were equally as worried about the possibility of HGE for society when compared to both the general Pew population $\left(\chi^{2}=0.05, p=0.82\right)$ and Pew African Americans $\left(\chi^{2}=0.11, p=0.73\right)$. As the large majority of SCD stakeholders in our sample identified as African American, we felt it was appropriate to compare their opinions to both groups.

Table 3. Comparison of SCD stakeholders with the general population and African Americans

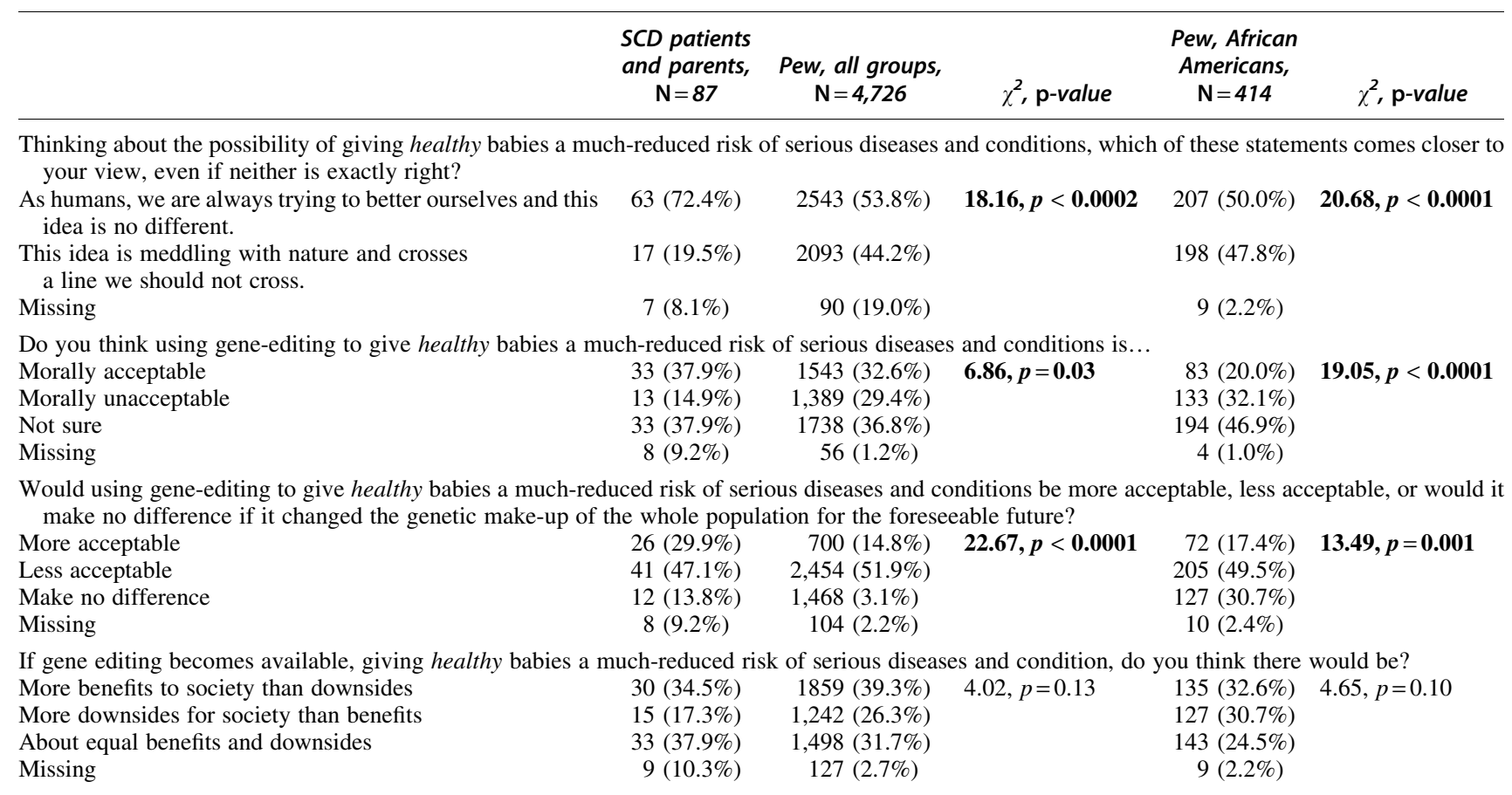

Bold values indicate statistical significance. 
Table 4. Themes from SCD stakeholder discussion around HGE

\begin{tabular}{|c|c|c|}
\hline Theme & Subtheme & Quotes \\
\hline \multirow[t]{7}{*}{ Concerns about HGE } & $\begin{array}{l}\text { Unintended consequences, } \\
\text { unknown effects of HGE }\end{array}$ & $\begin{array}{l}\text { "The auspices of [HGE]—it's for helping children, for babies, for this. But underneath that } \\
\text { umbrella could be a litany of other issues [side effects] that will arise from it." } \\
\text { (Individual with SCD) }\end{array}$ \\
\hline & $\begin{array}{l}\text { Misuse of HGE to change } \\
\text { non-health traits }\end{array}$ & $\begin{array}{l}\text { "So that's the thing that has me on the fence about it because it can easily go wrong and } \\
\text { be used in a way in which the next thing you know we have these super humans } \\
\text { running around-it sounds a little sci-fi but-at one point in time this was sci-fi, but } \\
\text { this is real." (Parent) }\end{array}$ \\
\hline & \multirow[t]{2}{*}{ Regulation of HGE technology } & $\begin{array}{l}\text { "Who decides what needs to be taken out and what doesn't? I mean, there's not, like, a } \\
\text { universal ethics committee that all agrees on the same thing." (Parent) }\end{array}$ \\
\hline & & $\begin{array}{l}\text { "I just had a bunch of thoughts about how people can misuse this. Even, like, the } \\
\text { government" (Individual with SCD) }\end{array}$ \\
\hline & \multirow[t]{2}{*}{ Moral and religious concerns } & $\begin{array}{l}\text { "It has a lot to do with individuals' religious beliefs. You don't alter DNA. If God } \\
\text { deems it perfect, then it's perfect." (Parent) }\end{array}$ \\
\hline & & $\begin{array}{l}\text { "I have beliefs and I believe God created you and he didn't make a mistake. So that, you } \\
\text { know, changing the genes of a child, that's a little bit too far for me." (Individual with } \\
\text { SCD) }\end{array}$ \\
\hline & $\begin{array}{l}\text { Genetic identity and connection } \\
\text { to future generations }\end{array}$ & $\begin{array}{l}\text { "It's like, this is going to change my whole family for generations to come, and I don't want } \\
\text { to be disconnected from those people that came before me, you know? I want to know who } \\
\text { my great-great-grandmother was, and I don't want to have my great-great-great- } \\
\text { grandchildren to be like, 'I don't know, because Mommy had a gene thing going on, so I } \\
\text { don't know where I come from."' (Parent) }\end{array}$ \\
\hline \multirow[t]{5}{*}{ Hopes about HGE } & \multirow[t]{3}{*}{$\begin{array}{l}\text { Elimination of worries related } \\
\text { to passing down the trait }\end{array}$} & $\begin{array}{l}\text { "You can't help who you decide who to build a life and a family with. And I don't } \\
\text { know if ... he have sickle [cell disease] —if that should really even play a factor into, } \\
\text { 'Do I love this person and want to spend the rest of my life with them?' and 'We're } \\
\text { going to have a family.' Like, I don't know if that's something that I really would } \\
\text { want to think about. So, if that happens and I had the option of correcting it, yes, I } \\
\text { would opt not to have a child with sickle cell." (Parent) }\end{array}$ \\
\hline & & $\begin{array}{l}\text { "I want this [sickle cell disease] out of my_-down the line, I don't want it to go any further. So, } \\
\text { if I could have another child that won't have the trait because of gene editing and our } \\
\text { lineage, we don't have that genetic disorder, that makes me happy. Not only happy, I'm } \\
\text { relieved." (Individual with SCD) }\end{array}$ \\
\hline & & $\begin{array}{l}\text { "If you have the opportunity of doing that [germline editing] while the child is still inside } \\
\text { of the female and knowing that it's not going to change anything besides that issue as } \\
\text { far as with the sickle cell, I would in my opinion." (Individual with SCD) }\end{array}$ \\
\hline & \multirow[t]{2}{*}{ Reducing disease burden } & $\begin{array}{l}\text { "If we had an opportunity to completely spare our children of any of the heartache that } \\
\text { they go through, the pain, the delirious pain sometimes, that they go through, I would } \\
\text { say yes in a heartbeat." (Parent) }\end{array}$ \\
\hline & & $\begin{array}{l}\text { "If we can get the embryo and remove it, why wouldn't I do that? Why wouldn't I } \\
\text { do that? For me ... if it is removing an illness, not going in and planning, picking what } \\
\text { you want, but just removing this illness that has been on your back your whole life and } \\
\text { you wouldn't want your kid to go through that, I am with it." (Individual with SCD) }\end{array}$ \\
\hline
\end{tabular}

HGE, heritable gene editing.

concerns centered around factors such as equitable access, "playing God", unintended consequences, and misuse of the technology. These concerns are similar to those shared by genetics professionals around the use of HGE, who discussed the concerns in the context of broader society and the negative impact HGE may have on the population as a whole. ${ }^{16}$ However, SCD stakeholders repeatedly mentioned their personal experiences with the disease, and it was often those experiences, accompanied by a desire to prevent future generations from experiencing similar hardship, that informed SCD stakeholders' positive perspective on the future of HGE. This is consistent with previous studies, which demonstrated that experience with a genetic condition shapes individuals' identity, attitudes, and knowledge. ${ }^{24,25}$

\section{Limitations}

There were several limitations to this study, including the sample size of the SCD stakeholder population and the confines of the survey measures. With this small sample size, we were unable to explore important variations in viewpoints influenced by factors such as nativity and immigration status. Furthermore, one third of the SCD stakeholders were involved in SCD advocacy groups, and therefore their opinions may not be generalizable to the full SCD population. In addition, while our study did give extra attention to making clear distinctions between SGE and HGE, challenges remained when communicating the technicalities of said distinction in a way that was both scientifically accurate and easily understood. Even though we informed participants about SGE and HGE through a video tool, it is still possible 
that SCD stakeholders may not have gained a complete understanding of SGE and HGE. Additionally, this study asked participants to consider hypothetical situations, and the results presented here may not reflect what participants would do when faced with the same choice in real life. ${ }^{26}$ Lastly, all the data presented in this study were collected prior to the controversial report of the birth of the first HGE babies in November 2018.

\section{Conclusion}

Our data reflect the importance of incorporating the opinions of patient communities into the continuing dialogue surrounding HGE, and suggest that these populations have a unique perspective to offer that is influenced by their burden of the diseases. One area of need that the scientific community should focus on is increasing the sample size of the surveyed SCD population, as well as that of other populations suffering from genetic diseases. In addition, it is important that we emphasize the need for clarity and consistency of the language used to query opinions on gene editing. Variation in the language of past opinion polls may be a contributing factor to variation in the responses of study populations. ${ }^{19}$ While many publications on the topic have called for an increased focus on public and stakeholder opinions on the issue, ${ }^{4,11,13}$ it is also imperative that we focus also on increasing the quality and reliability of these results. Finally, our study reveals a need for further exploration of the distinction between moral concerns and clinical use of HGE if it is determined to be safe and effective. Fully understanding opinions about HGE may warrant an acknowledgement that individuals may recognize moral and scientific quandary regarding the technology without necessarily allowing that recognition to impede their support of its use to eradicate a disease impacting them and their family.

Our results suggest that SCD stakeholders offer a unique and nuanced lens on the prospect of HGE that is influenced by personal experience with genetic disease. In addition, the trends we identified suggest that SCD stakeholders' positive view of the future of HGE, if it is safe and effective, does not stem from a neglect to recognize the complex nature of HGE, but rather suggests that the influence of disease burden may supersede moral concerns.

\section{Acknowledgments}

We would like to acknowledge all individuals that provided their opinions, views, and voices to the conversation of gene editing who generously offered their time to participate in this study. This work was supported in part by the Division of Intramural Research, National Human Genome Research Institute (NHGRI) ZIAHG
200394. The findings of the study were presented at the European Society of Human Genetics Annual Meeting, June 16, 2019 in Gothenburg, Sweden.

The US National Institutes of Health will not fund any use of gene-editing technologies in human embryos. The opinions of the study participants' and authors expressed do not reflect the policies or positions of the U.S. National Human Genome Research Institute, U.S. National Institutes of Health, or the U.S. Department of Health and Human Services.

\section{Author Disclosure Statement}

K.E.O. was the co-chair of the American Society of Human Genetics statement on germline gene editing. No competing financial interests exist for the remaining authors.

\section{Funding Information}

This work was supported in part by the Division of Intramural Research, National Human Genome Research Institute (NHGRI) ZIAHG200394.

\section{Supplementary Material}

Supplementary Data 1

Supplementary Data 2

\section{References}

1. National Academies of Science, Engineering, and Medicine. Human Genome Editing: Science, Ethics, and Governance. Washington, DC: National Academies Press, 2017.

2. Daley GQ, Lovell-Badge R, Steffann J. After the storm-a responsible path for genome editing. N Engl J Med 2019;380:897-899. DOI: 10.1056/ NEJMp1900504.

3. Charo RA. Rogues and regulation of germline editing. $N$ Engl J Med 2019;380:976-980. DOI: 10.1056/NEJMms1817528.

4. Allyse $M$, Bombard $Y$, Isasi $R$, et al. What do we do now?: Responding to claims of germline gene editing in humans. Genet Med 2019; 21:2181-2183. DOI: 10.1038/s41436-019-0492-3.

5. Cyranoski D, Ledford H. Genome-edited baby claim provokes international outcry. Nature 2018;563:607-608. DOI: 10.1038/d41586-01807545-0.

6. National Academies of Science, Engineering, and Medicine. Second International Summit on Human Genome Editing: Continuing the Global Discussion: Proceedings of a Workshop-in Brief. Washington, DC: National Academies Press, 2019.

7. Collins FS. NIH supports call for moratorium on clinical uses of germline gene editing. Nature 2018;567:175. DOI: 10.1038/d41586019-00814-6.

8. Germline gene-editing research needs rules. Nature 2019;567:145. DOI: 10.1038/d41586-019-00788-5.

9. Lander ES, Baylis F, Zhang F, et al. Adopt a moratorium on heritable genome editing. Nature 2019;567:165-168. DOI: 10.1038/d41586-01900726-5.

10. Collins FS. Statement on NIH funding of research using gene-editing technologies in human embryos. The NIH Director, 2015. Available online at https://www.nih.gov/about-nih/who-we-are/nih-director/ statements/statement-nih-funding-research-using-gene-editingtechnologies-human-embryos (last accessed June 15, 2019).

11. Burall S. Rethink public engagement for gene editing. Nature 2018;555:438-439. DOI: 10.1038/d41586-018-03269-3.

12. de Wert $G$, Pennings $G$, Clarke $A$, et al. Human germline gene editing: recommendations of ESHG and ESHRE. Eur J Hum Genet 2018;26:445449. DOI: 10.1038/s41431-017-0076-0. 
13. McCaughey T, Budden DM, Sanfilippo PG, et al. A need for better understanding is the major determinant for public perceptions of human gene editing. Hum Gene Ther 2019;30:36-43. DOI: 10.1089/ hum.2018.033.

14. Vertex Pharmaceuticals, Inc., CRISPR Therapeutics. NCT03745287: A Safety and Efficacy Study Evaluating CTX001 in Subjects with Severe Sickle Cell Disease, 2021.

15. Wu Y, Zeng J, Roscoe BP, et al. Highly efficient therapeutic gene editing of human hematopoietic stem cells. Nat Med 2019;25:776-783. DOI: 10.1038/s41591-019-0401-y.

16. Armsby AJ, Bombard Y, Garrison NA, et al. International attitudes of genetics professionals toward human gene editing. CRISPR J 2019;2:331339. DOI: $10.1089 /$ crispr.2019.0020.

17. Somerville RCJ, Hassol SJ. Communicating the science of climate change. Phys Today 2011;64:48-53. DOI: 10.1063/pt.3.1296.

18. Brownell SE, Price JV, Steinman L. Science communication to the general public: why we need to teach undergraduate and graduate students this skill as part of their formal scientific training. J Undergrad Neurosci Educ 2013;12:E6-E10.

19. Blendon RJ, Gorski MT, Benson JM. The public and the gene-editing revolution. N Engl J Med 2016;374:1406-1411. DOI: 10.1056/ NEJMp1602010.

20. Persaud ADS, Blizinsky K, Bonham V. A CRISPR focus on attitudes and beliefs toward somatic genome editing from stakeholders within the sickle cell disease community. Genet Med 2019;21:1726-1734. DOI: 10.1038/s41436-018-0409-6.

21. Abrams LR, McBride CM, Hooker GW, et al. The many facets of genetic literacy: assessing the scalability of multiple measures for broad use in survey research. PLoS One 2015;10:e0141532. DOI: 10.1371/journal.pone.0141532.

22. Pew Research Center. Public views of gene editing for babies depend on how it would be used, 2018. Available online at https:// www.pewresearch.org/science/2018/07/26/public-views-of-geneediting-for-babies-depend-on-how-it-would-be-used/ (last accessed June 15, 2019).

23. Coller BS. Ethics of human genome editing. Annu Rev Med 2019;70:289305. DOI: 10.1146/annurev-med-112717-094629.

24. Klitzman R. "Am I my genes?": questions of identity among individuals confronting genetic disease. Genet Med 2009;11:880-889. DOI: 10.1097/ GIM.0b013e3181bfd212.

25. Chapman E. The social and ethical implications of changing medical technologies: the views of people living with genetic conditions. J Health Psychol 2002;7:195-206. DOI: 10.1177/135910530200700 2458.

26. Bostyn DH, Sevenhant S, Roets A. Of mice, men, and trolleys: hypothetical judgment versus real-life behavior in trolley-style moral dilemmas. Psychol Sci 2018;29:1084-1093. DOI: 10.1177/095679761775 2640. 